\title{
Congenital carotid hypoplasia in ischemic stroke
}

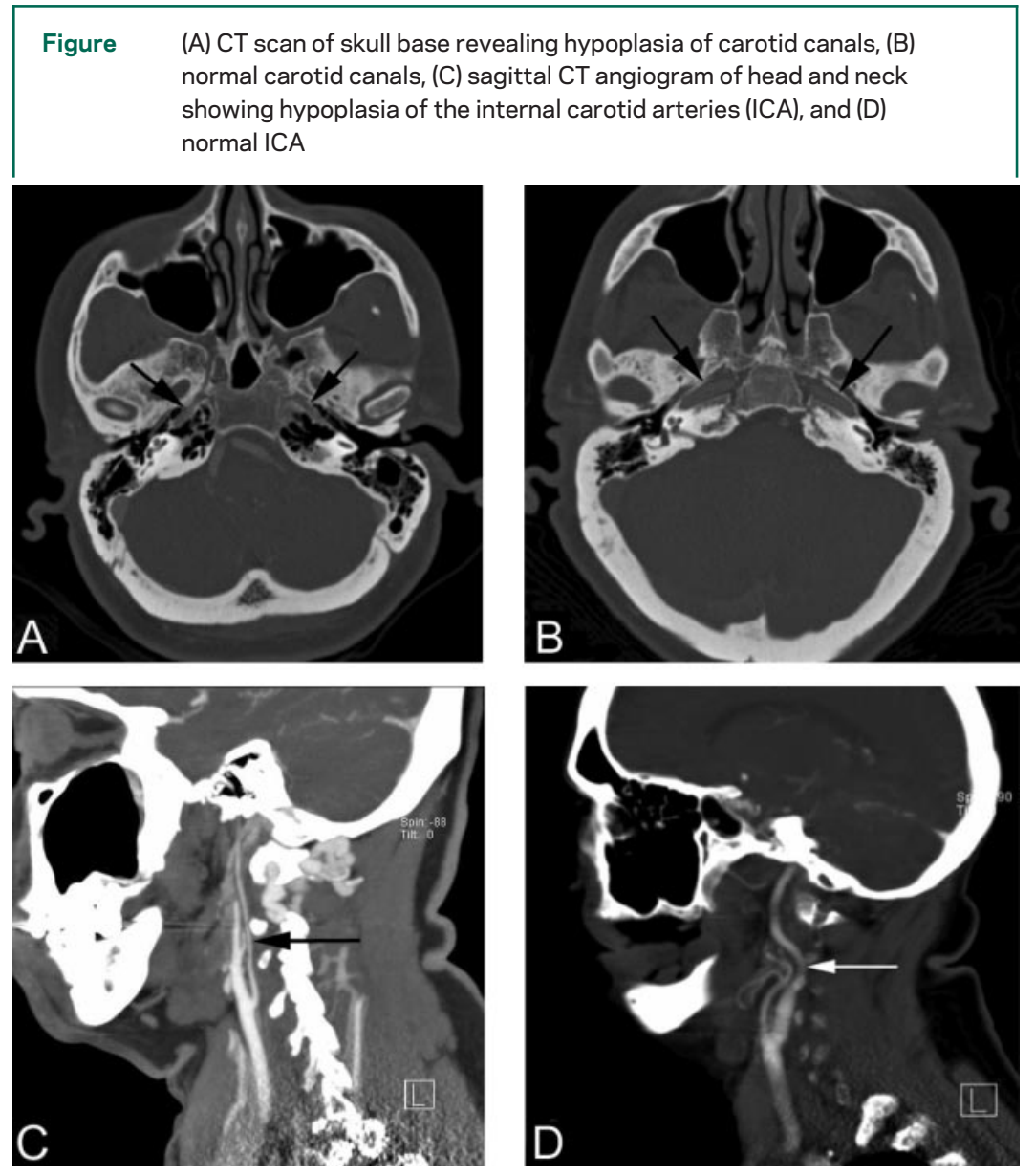

A 53-year-old woman with hyperlipidemia presented with acute onset left-sided weakness and slurred speech. Neurologic examination was remarkable for left central facial droop, left hemiparesis, and dysarthria. Imaging revealed a right insular ischemic stroke and hypoplasia of the internal carotid arteries (figure).

Congenital hypoplasia of the carotid arteries is rare. To differentiate carotid hypoplasia from carotid dissection or atherosclerotic disease, CT of the skull base reveals small carotid canals not seen in the other conditions. The enlargement of collaterals-particularly the posterior communicating arteries and posterior circulation-are indicative of carotid hypoplasia. ${ }^{1}$ This is important when management with anticoagulation or endarterectomy is considered.

Noor Sachdev, MD, Somchai Laowattana, MD, PhD, Laura Belorgey Bonds, MD, and Gulam Hussain Thaver, MD, Houston, TX

Disclosure: The authors report no disclosures.

Address correspondence and reprint requests to Dr. Somchai Laowattana, Department of Neurology, Baylor College of Medicine, One Baylor Plaza, Houston, TX77030; laowatta@bcm.tmc.edu

1. Ide C, De Coene B, Mailleux P, Baudrez V, Ossemann M, Trigaux JP. Hypoplasia of the internal carotid artery: a noninvasive diagnosis. Eur Radiol 2000;10:1865-1870. 


\section{Neurology}

Congenital carotid hypoplasia in ischemic stroke

Noor Sachdev, Somchai Laowattana, Laura Belorgey Bonds, et al.

Neurology 2008;70;2086

DOI 10.1212/01.wnl.0000313382.94367.7f

This information is current as of May 27, 2008

\section{Updated Information \&} Services

References

Subspecialty Collections

Permissions \& Licensing

Reprints including high resolution figures, can be found at: http://n.neurology.org/content/70/22/2086.full

This article cites 1 articles, 0 of which you can access for free at: http://n.neurology.org/content/70/22/2086.full\#ref-list-1

This article, along with others on similar topics, appears in the following collection(s):

\section{All Cerebrovascular disease/Stroke}

http://n.neurology.org/cgi/collection/all_cerebrovascular_disease_strok

e

Carotid artery dissection

http://n.neurology.org/cgi/collection/carotid_artery_dissection

CT

http://n.neurology.org/cgi/collection/ct

Other cerebrovascular disease/ Stroke

http://n.neurology.org/cgi/collection/other_cerebrovascular_disease_st roke

Stroke in young adults

http://n.neurology.org/cgi/collection/stroke_in_young_adults

Information about reproducing this article in parts (figures,tables) or in its entirety can be found online at:

http://www.neurology.org/about/about_the_journal\#permissions

Information about ordering reprints can be found online:

http://n.neurology.org/subscribers/advertise

Neurology ${ }^{\circledR}$ is the official journal of the American Academy of Neurology. Published continuously since 1951, it is now a weekly with 48 issues per year. Copyright . All rights reserved. Print ISSN: 0028-3878. Online ISSN: 1526-632X.

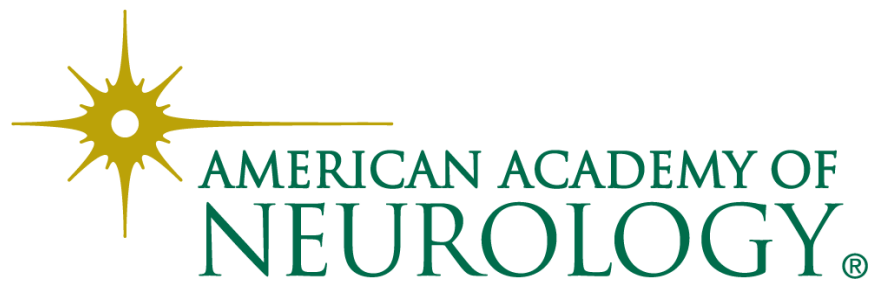

